\title{
Trends in Cuba's Cancer Incidence (1990 to 2003) and Mortality (1990 to 2007)
}

\author{
Yaima Galán, MPH, Leticia Fernández, MD, PhD, Priscila Torres, MD, Mariela García, DDS, MPH
}

\begin{abstract}
Introduction Cancer has been the second cause of death in Cuba since 1958. The National Cancer Registry (NCR) and the National Statistics Division of the Ministry of Public Health provide incidence, mortality and other relevant epidemiological data on the disease, as a basis for analysis and decision-making in public health planning for cancer control.

Objectives Describe trends in incidence and mortality of cancer in Cuba overall and by sex since 1990, and analyze the most current 3-year data for frequent types and risk of developing and dying from cancer, by age group, sex, site, and province.

Methods Cancer incidence and mortality were described using ageadjusted rates based on standard world population for 1990-2003 and 1990-2007, respectively. Crude and age-adjusted rates were calculated for the most common sites (excluding nonmelanoma skin cancer) by sex using the latest 3-year incidence data available (20012003) from the National Cancer Registry and mortality data (20052007) from the National Statistics Division of the Ministry of Public Health. To compare risk of developing and dying from cancer among Cuban provinces, age-adjusted rates were distributed in quartiles.
\end{abstract}

Results Cancer incidence and mortality have increased in both sexes since 1990. In 2001-2003, an average of 23,710 new cancer cases were diagnosed annually (excluding nonmelanoma skin cancer), and the average annual risk of developing cancer was 216.5 per 100,000 population for men and 204.0 per 100,000 population for women. Between 2005 and 2007, there were 19,671 average annual deaths from cancer in Cuba. The risk of developing and dying from cancer varies by age group and by geographic location but was highest in Havana City province. The sites with highest incidence and mortality were lung, female breast, prostate, colon, and uterine cervix.

Conclusions Cancer incidence and mortality are increasing in Cuba, and the differences by site, age, sex and geographical distribution analyzed in this article, as well as recommended further research, should serve to inform adoption and implementation of more effective strategies for the Ministry of Public Health's national Comprehensive Cancer Control Program.

Keywords: Cancer, epidemiology, incidence, mortality, death rate, age distribution, sex distribution, registries, Cuba

\section{INTRODUCTION}

Cancer is a serious global health problem that is expected to grow rapidly in the next few years, due mainly to aging populations in many countries, adoption of unhealthy lifestyles and environmental carcinogens, among other factors.[1] According to the International Agency for Research on Cancer (IARC), in 2002, an estimated 11 million people were diagnosed with cancer and 7 million died from malignant disease.[2] By 2020, it is predicted that the majority of 16 million new cancer cases and 12 million cancer deaths will occur in developing countries, which lack adequate resources to confront this growing health problem.[2-4]

In Cuba, cancer is the leading cause of death in the population aged 1-64 years, and the second cause of death after cardiovascular diseases in the population aged $\geq 65$ years. It is the disease most influencing years of potential life lost,[5] and its impact on disability-adjusted life years is growing.[6,7]

Cancer incidence and mortality vary widely around the world.[2] Differences in distribution of cancer types between industrialized and developing countries are similar to the differences between socio-economic groups in industrialized nations. [8,9] In developing countries, the most frequent cancers are associated with viruses and infectious diseases;[9] however, risk factors such as smoking, obesity, unhealthy diets and lack of physical exercise, are increasing in these countries. $[9,10]$

Although Cuba is a developing country in economic terms, its demographic indicators are comparable to those of developed countries. Infant mortality, for example, is very low and in some cases below developed country rates,[11-13] The similarity can also been seen in the causes associated with the growing risk of developing cancer. Control of infections diseases and improved population health as a result of universal health care has resulted in a growing population aged $\geq 60$ years, the age group with the highest risk of developing cancer.[11-14]

By the end of $2007,16.6 \%$ of the Cuban population was aged $\geq 60$ years, over half a million more than 20 years ago.[15-17] An accelerated aging process is predicted, with Cubans aged $\geq 60$ years making up $29.9 \%$ of the total population by 2030 .[16,17] This trend is typical of a very advanced demographic transition that is practically unique among developing countries, whichalong with so-called "westernized" lifestyle changes—contributes to an increase in cancer-related risk factors.[17,18]

Cuba's National Cancer Registry (NCR)—a population-based information system for collecting, processing and analyzing data on all patients diagnosed with cancer-was created in $1964[19,20]$ and upgraded in 1986 to include mandatory reporting and improved data management and validation systems.[21,22] Today the NCR is part of the national public health system's cancer prevention and control strategy, introduced in 1987 with the aim of lowering cancer incidence and mortality, and increasing survival and quality of life.[23,24] One of the main goals of the current strategy is a $15 \%$ reduction in mortality from all malignant tumors by $2015 .[25]$

During the period 1986-1990, the most frequent cancer sites were lung, skin and colorectal for both sexes; prostate and blad- 
der among men; and breast and cervix among women. Sites with highest mortality were lung and colon-rectum in both sexes; prostate, stomach and larynx in men; and breast, cervix, liver and gall bladder in women. The risk of developing cancer was 218.2 per 100,000 men and 183.7 per 100,000 women, while the risk of dying from cancer was estimated at 138.4 per 100,000 men and 95.1 per 100,000 women.[26] According to incidence rates estimated annually by the NCR, since 2000 , these rates have increased.[14]

This article's objective is to describe trends in incidence and mortality of cancer in Cuba overall and by sex since 1990, and analyze the most current 3-year data for frequent types and risk of developing and dying from cancer, by age group, sex, site, and geographical distribution (province).

\section{METHODS}

Population data for the 1990-2007 series were obtained from the National Statistics Bureau (ONE, its Spanish acronym); cancer incidence data by sex were obtained from 1990 to 2003 from the National Cancer Registry, and mortality data by sex from 1990 to 2007 from the Ministry of Public Health's National Statistics Division.

For more detailed analysis of the most current cancer incidence and mortality, and in order to obtain more precise estimates by minimizing impact of random fluctuations from one year to the next, age-adjusted rates based on the standard world population were calculated for 3-year periods using the direct method.[27] Rates were expressed as cases per 100,000 population.

Topographical sites were defined using the International Classification of Diseases for Oncology, First Edition (ICD-O-1).[28] Although squamous cell and basal cell skin carcinomas have the highest incidence, they were excluded because mortality from these cancers is very low.

For analysis of incidence and mortality trends for all cancer sites, a linear regression model was adjusted to the logarithm of the annual age-adjusted rates.[27] The linear regression straight line slope multiplied by 100 was interpreted as the average annual percent change in rates.

\section{Incidence}

Age-adjusted rates were calculated based on the standard world population of 1990-2003. A more detailed analysis of the risk of developing cancer by sex, province of residence, site, and age group was made for the period 2001-2003, the 3-year period for which the most recent NCR data was available. Crude rates, specific rates by age group $(0-14,15-29,30-44,45-59$, and $\geq 60$ years), and age-adjusted rates by site and sex were calculated.

To compare the risk of developing cancer by sex and by province, age-adjusted rates were distributed in quartiles. Four risk groups were thus defined and classified as very high (>75), high (50-75), medium (25-50) and low (<25) risk. This analysis did not include the Isle of Youth special municipality, because its population is too small for comparison.

Mortality

Age-adjusted rates were calculated [26] for the period 19902007. A more detailed analysis of cancer mortality by sex, province of residence, site and age group was made for the period 2005-2007, using the most recent available 3-year data. Crude rates, specific rates by age group (0-14, 15-29, 30-44, $45-59$, and $\geq 60$ years), and age-adjusted rates by site and sex were calculated.

Age-adjusted rates were distributed in quartiles to compare the risk of dying from cancer by sex and province, as described for comparing incidence above. Again, the Isle of Youth was excluded from the analysis.

\section{RESULTS \\ Incidence}

As shown in Figure 1, between 1990 and 1995, cancer incidence in Cuba declined for both females $(p=0.009)$ and males $(p=0.0012)$, with a $2 \%$ average annual percent change among females and $1.3 \%$ among males, while in the period 1996-2003, incidence rose for both sexes with a $1 \%$ average annual percent change among women $(p=0.0307)$ and $0.8 \%$ among men $(p=0.0304)$. In the period 2001-2003, an average of 23,710 new cancer cases per year were diagnosed in Cuba, $51.3 \%$ of them in men. Average annual risk of developing cancer was 216.5 per 100,000 men and 204.9 per 100,000 women (Table 1). Incidence was highest in Havana City province $(25.5 \%)$, followed by Santiago de Cuba $(8.7 \%)$ and Villa Clara $(8.4 \%)$.

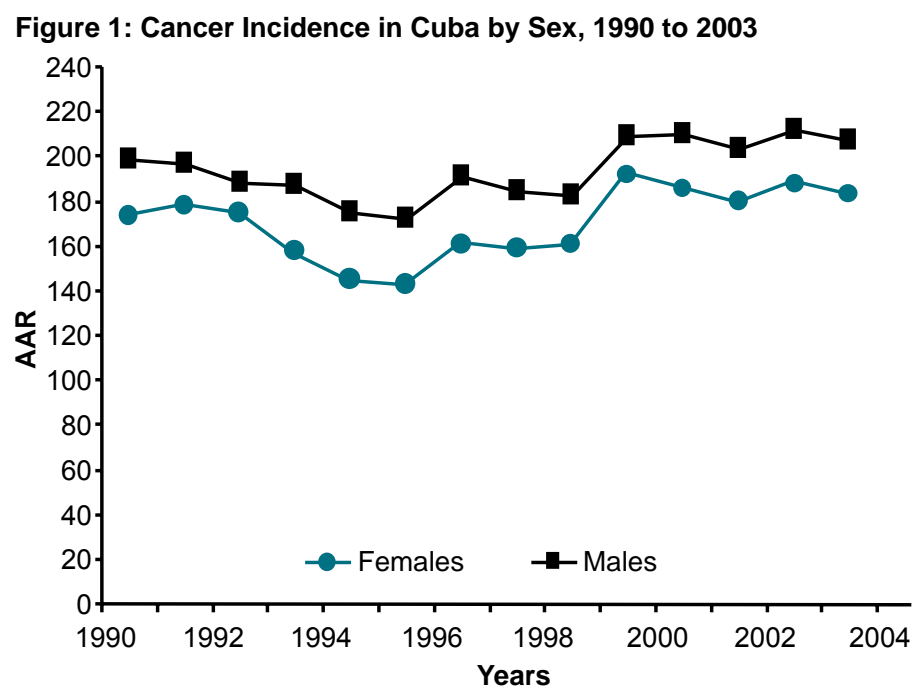

AAR: Age-adjusted rate (standard world population) per 100,000 population Source: National Cancer Registry

The provinces showing highest overall risk of developing cancer for males were Havana City, Santiago de Cuba and Granma, and those with highest risk for females were Havana City, Santiago de Cuba and Villa Clara. The provinces with lowest risk for males were Pinar del Río, Sancti Spíritus and Las Tunas; and those with lowest risk for females were Ciego de Ávila, Holguín and Guantánamo. Risk was high or intermediate in the remaining provinces (Figure 2).

The most common sites, accounting for $>50 \%$ of new cases, were lung, prostate, larynx, colon and bladder in men; and breast, cervix, lung, colon and uterus in women. Lung cancer presented the highest risk for men, followed by prostate cancer; in women, risk was highest for breast cancer, followed by cervical and lung cancers (Table 2). 
Table 1: Risk of Developing Cancer in Cuba by Sex and Province, 2001 to 2003

\begin{tabular}{|c|c|c|c|c|c|c|c|c|}
\hline \multirow{3}{*}{ Province } & \multirow{2}{*}{\multicolumn{2}{|c|}{ Total }} & \multicolumn{3}{|c|}{ Males } & \multicolumn{3}{|c|}{ Females } \\
\hline & & & \multirow[b]{2}{*}{ No. } & \multicolumn{2}{|c|}{ Rate $^{*}$} & \multirow{2}{*}{ No. } & \multicolumn{2}{|c|}{ Rate $^{*}$} \\
\hline & No. & $\%$ & & Crude & Adjusted & & Crude & Adjusted \\
\hline Pinar del Río & 1395 & 5.9 & 704 & 186.5 & 148.6 & 691 & 190.8 & 155.8 \\
\hline Havana & 1394 & 5.9 & 714 & 200.6 & 150.0 & 680 & 191.9 & 139.9 \\
\hline Havana City & 6034 & 25.5 & 2887 & 277.4 & 206.6 & 3147 & 272.8 & 173.5 \\
\hline Matanzas & 1397 & 5.9 & 742 & 222.0 & 166.6 & 655 & 198.5 & 148.7 \\
\hline Villa Clara & 1999 & 8.4 & 1042 & 247.4 & 165.7 & 957 & 229.0 & 157.3 \\
\hline Cienfuegos & 807 & 3.4 & 422 & 210.0 & 158.4 & 385 & 195.7 & 147.8 \\
\hline Sancti Spíritus & 987 & 4.2 & 515 & 218.0 & 148.0 & 472 & 207.4 & 148.9 \\
\hline Ciego de Ávila & 755 & 3.2 & 433 & 207.0 & 156.6 & 322 & 158.7 & 124.6 \\
\hline Camagüey & 1623 & 6.9 & 856 & 214.7 & 166.6 & 767 & 194.7 & 153.4 \\
\hline Las Tunas & 916 & 3.9 & 470 & 173.1 & 142.4 & 446 & 171.2 & 145.1 \\
\hline Holguín & 1815 & 7.7 & 975 & 184.2 & 149.7 & 840 & 165.6 & 136.2 \\
\hline Granma & 1552 & 6.6 & 821 & 192.7 & 170.4 & 731 & 178.6 & 155.6 \\
\hline Santiago de Cuba & 2059 & 8.7 & 1081 & 207.6 & 184.6 & 978 & 187.9 & 159.8 \\
\hline Guantánamo & 813 & 3.4 & 429 & 164.6 & 154.5 & 384 & 150.5 & 139.6 \\
\hline Isle of Youth & 144 & 0.6 & 71 & 174.4 & 201.6 & 73 & 184.1 & 185.1 \\
\hline Total** & 23,710 & 100.0 & 12,170 & & & 11,540 & & \\
\hline Average & & & & 216.5 & 169.0 & & 204.9 & 153.6 \\
\hline
\end{tabular}

No.: Average annual number of new cases

*per 100,000 population

**Includes 20 cases with unknown province of residence ( 8 men and 12 women). The percentage is calculated based on 23,710 cases.

Source: National Cancer Registry

Figure 2: Risk of Developing Cancer in Cuba by Sex and Province, 2001 to 2003
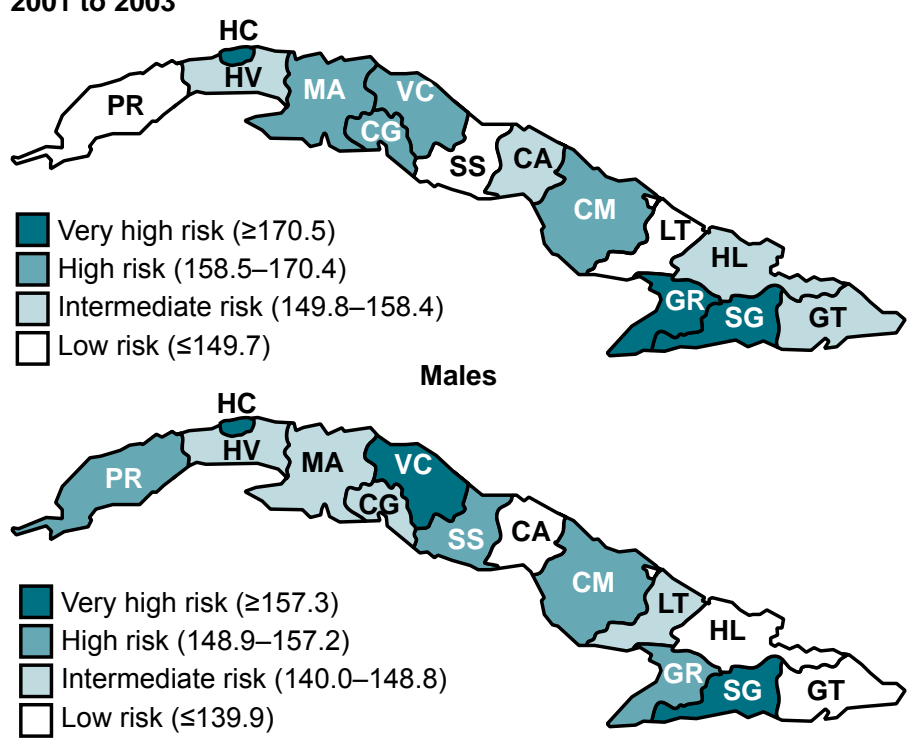

Females

PR: Pinar del Río, HV Havana, HC: Havana City, MA: Matanzas,

VC: Villa Clara, CG: Cienfuegos, SS: Sancti Spíritus, CA: Ciego de

Ávila, CM: Camagüey, LT: Las Tunas, HL: Holguín, GR: Granma, SG:

Santiago de Cuba, GT: Guantánamo

Average annual rates per 100,000 population

Source: National Cancer Registry

Cancer in the population aged $<15$ years accounted for $1.2 \%$ of all new cancer cases in Cuba in 2001-2003 (Table 3). During that period, an average of 276 children were diagnosed with cancer per year, with a specific rate of 11.6 per 100,000 population. Leukemias were the most common type, followed by lymphomas and central nervous system tumors.

In the population aged $>15$ years, overall risk of developing cancer was higher among men than women. However, in the group aged $<60$ years, the risk was greater for women, due fundamen- tally to the high incidence of breast and cervical cancers. The risk of developing cancer was low among males in the group aged 15-29 years, with leukemias and lymphomas exhibiting the highest rates. Females in that age group, however, showed a high risk for cervical cancer. In the group aged 30-44 years, incidence rates were highest for bronchial and lung cancer in men and for cervical cancer in women. In the group aged 45-59 years, lung cancer was highest among men and breast cancer among women. In the group aged $\geq 60$ years, lung and prostate cancer had the highest incidence among men, and breast and lung cancer predominated among women; colon cancer had the third highest incidence in both men and women, with higher rates for women (Table 4).

\section{Mortality}

In the period 1990-2007, cancer mortality in Cuba increased slightly for both females $(p=0.0108)$ and males $(p=0.0007)$, with a $0.28 \%$ average annual percent change for each (Figure 3 ).
Average annual cancer deaths numbered 19,671 during the period 2005-2007. Males faced the highest risk, as nearly $60 \%$ of those who died were men (Table 5). Approximately $25 \%$ of all cancer deaths occurred in Havana City province, where risk of dying of cancer was highest for both sexes, followed by Holguín and Santiago de Cuba. For males only, however, the provinces with second and third highest risk of dying from cancer were Matanzas and Las Tunas; for females only, risk was higher Camagüey and Guantánamo (Figure 4).

Table 2: Cancer Incidence in Cuba by Site, 2001 to 2003

\begin{tabular}{|c|c|c|c|c|}
\hline Site & Cases & $\%$ & $\mathrm{CR}^{*}$ & $\mathrm{AAR}^{* *}$ \\
\hline \multicolumn{5}{|c|}{ Men } \\
\hline Lung & 2899 & 23.8 & 51.6 & 40.7 \\
\hline Prostate & 2184 & 17.9 & 38.8 & 26.9 \\
\hline Larynx & 752 & 6.2 & 13.4 & 11.1 \\
\hline Colon & 716 & 5.9 & 12.7 & 9.7 \\
\hline Bladder & 590 & 4.8 & 10.5 & 8.1 \\
\hline Oral cavity & 576 & 4.7 & 10.3 & 8.3 \\
\hline Stomach & 516 & 4.2 & 9.2 & 7.2 \\
\hline Hematopoietic system & 475 & 3.9 & 8.5 & 7.4 \\
\hline Lymph nodes & 425 & 3.5 & 7.6 & 6.5 \\
\hline Esophagus & 385 & 3.2 & 6.8 & 5.6 \\
\hline \multirow{2}{*}{ All sites } & 12,170 & 100.0 & 216.5 & 169.0 \\
\hline & \multicolumn{4}{|l|}{ Women } \\
\hline Breast & 2445 & 21.2 & 43.4 & 33.6 \\
\hline Cervix & 1404 & 12.2 & 24.9 & 18.0 \\
\hline Lung & 1335 & 11.6 & 23.7 & 17.9 \\
\hline Colon & 1018 & 8.8 & 18.1 & 12.1 \\
\hline Uterus & 469 & 4.1 & 8.3 & 6.6 \\
\hline Hematopoietic system & 439 & 3.8 & 7.8 & 6.6 \\
\hline Ovary & 354 & 3.1 & 6.3 & 5.1 \\
\hline Pancreas & 328 & 2.8 & 5.8 & 4.0 \\
\hline Rectum & 314 & 2.7 & 5.6 & 4.2 \\
\hline Stomach & 314 & 2.7 & 5.6 & 4.0 \\
\hline All sites & 11,540 & 100.0 & 204.9 & 153.6 \\
\hline
\end{tabular}

Cases: Average annual number of cases for the 3-year period analyzed

*Average crude rate per 100,000 population.

${ }^{* *}$ AAR: Age-adjusted rate (standard world population) per 100,000 population Source: National Cancer Registry 
Table 3: Cancer Incidence in Cuban Population Aged <15 Years by Diagnosis and Age Group, 2001 to 2003

\begin{tabular}{|c|c|c|c|c|c|c|c|c|c|c|}
\hline \multirow{3}{*}{ Diagnosis } & \multicolumn{8}{|c|}{ Age Group (in years) } & \multirow{2}{*}{\multicolumn{2}{|c|}{ Total }} \\
\hline & \multicolumn{2}{|c|}{$<1$} & \multicolumn{2}{|c|}{$1-4$} & \multicolumn{2}{|c|}{$5-9$} & \multicolumn{2}{|c|}{$10-14$} & & \\
\hline & No. & SR & No. & SR & No & SR & No. & SR & No. & AAR \\
\hline Leukemia & 6 & 3.8 & 30 & 5.1 & 28 & 3.5 & 25 & 2.9 & 89 & 3.7 \\
\hline Lymphocytic & 2 & 1.3 & 24 & 4.0 & 22 & 2.8 & 18 & 2.0 & 66 & 2.7 \\
\hline $\begin{array}{l}\text { Acute non- } \\
\text { lymphocytic }\end{array}$ & 1 & 0.9 & 3 & 0.6 & 4 & 0.5 & 4 & 0.5 & 12 & 0.5 \\
\hline $\begin{array}{l}\text { Chronic } \\
\text { myelogenous }\end{array}$ & 0 & 0.0 & 1 & 0.1 & 0 & 0.0 & 2 & 0.2 & 3 & 0.1 \\
\hline Others specified & 0 & 0.0 & 1 & 0.1 & 0 & 0.0 & 0 & 0.0 & 1 & 0.0 \\
\hline Unspecified & 2 & 1.6 & 2 & 0.3 & 1 & 0.1 & 2 & 0.2 & 7 & 0.3 \\
\hline Lymphoma & 0 & 0.0 & 14 & 2.4 & 20 & 2.5 & 17 & 1.9 & 51 & 2.1 \\
\hline Hodgkin & 0 & 0.0 & 2 & 0.4 & 7 & 0.8 & 8 & 0.9 & 17 & 0.7 \\
\hline Non-Hodgkin & 0 & 0.0 & 9 & 1.6 & 12 & 1.5 & 7 & 0.8 & 28 & 1.2 \\
\hline Burkitt & 0 & 0.0 & 1 & 0.1 & 1 & 0.1 & 1 & 0.1 & 3 & 0.1 \\
\hline $\begin{array}{l}\text { Lymphoreticular } \\
\text { neoplasms }\end{array}$ & 0 & 0.0 & 1 & 0.1 & 0 & 0.0 & 0 & 0.0 & 1 & 0.0 \\
\hline Unspecified & 0 & 0.0 & 1 & 0.2 & 0 & 0.0 & 1 & 0.2 & 2 & 0.1 \\
\hline $\begin{array}{l}\text { Central Nervous } \\
\text { System }\end{array}$ & 3 & 2.0 & 16 & 2.6 & 15 & 1.8 & 13 & 1.5 & 46 & 1.9 \\
\hline Neuroblastoma & 5 & 3.1 & 4 & 0.7 & 2 & 0.3 & 1 & 0.2 & 12 & 0.5 \\
\hline Retinoblastoma & 3 & 1.8 & 2 & 0.4 & 1 & 0.1 & 0 & 0.0 & 6 & 0.3 \\
\hline Renal tumors & 3 & 1.8 & 13 & 2.2 & 4 & 0.5 & 1 & 0.1 & 21 & 0.8 \\
\hline Wilms tumor & 2 & 1.6 & 12 & 2.0 & 4 & 0.5 & 1 & 0.1 & 19 & 0.8 \\
\hline $\begin{array}{l}\text { Renal cell } \\
\text { carcinoma }\end{array}$ & 0 & 0.0 & 1 & 0.1 & 0 & 0.0 & 0 & 0.0 & 1 & 0.0 \\
\hline cified & 0 & 0.2 & 1 & 0.1 & 0 & 0.0 & 0 & 0.0 & 1 & 0.0 \\
\hline blastoma & 1 & 0.9 & 1 & 0.1 & 0 & 0.0 & 0 & 0.0 & 2 & 0.1 \\
\hline Bone tumors & 0 & 0.2 & 2 & 0.3 & 1 & 0.1 & 10 & 1.1 & 11 & 0.5 \\
\hline $\begin{array}{l}\text { Soft tissue } \\
\text { sarcoma }\end{array}$ & 2 & 1.6 & 4 & 0.7 & 5 & 0.6 & 3 & 0.3 & 15 & 0.6 \\
\hline Germ cell tumor & 1 & 0.9 & 1 & 0.1 & 1 & 0.1 & 3 & 0.3 & 6 & 0.3 \\
\hline $\begin{array}{l}\text { Thyroid } \\
\text { carcinoma }\end{array}$ & 0 & 0.0 & 0 & 0.0 & 0 & 0.0 & 3 & 0.4 & 3 & 0.1 \\
\hline $\begin{array}{l}\text { Nasopharyngeal } \\
\text { carcinoma }\end{array}$ & 0 & 0.0 & 0 & 0.0 & 0 & 0.0 & 0 & 0.0 & 1 & 0.0 \\
\hline Melanoma & 0 & 0.0 & 0 & 0.0 & 0 & 0.0 & 1 & 0.1 & 1 & 0.0 \\
\hline $\begin{array}{l}\text { Others, } \\
\text { unspecified }\end{array}$ & 3 & 1.8 & 3 & 0.6 & 4 & 0.5 & 7 & 0.8 & 17 & 0.7 \\
\hline All sites & 27 & 17.7 & 90 & 15.2 & 81 & 10.0 & 84 & 9.5 & 276 & 11.6 \\
\hline
\end{tabular}

No.: Average annual number of cases for the 3-year period analyzed

SR: Specific rate per 100,000 population

AAR: Age-adjusted rate to standard world population

Source: National Cancer Registry

Table 4: Cancer Incidence in Cuban Population Aged $\geq 15$ Years by Site, Age Group and Sex, 2001 to 2003

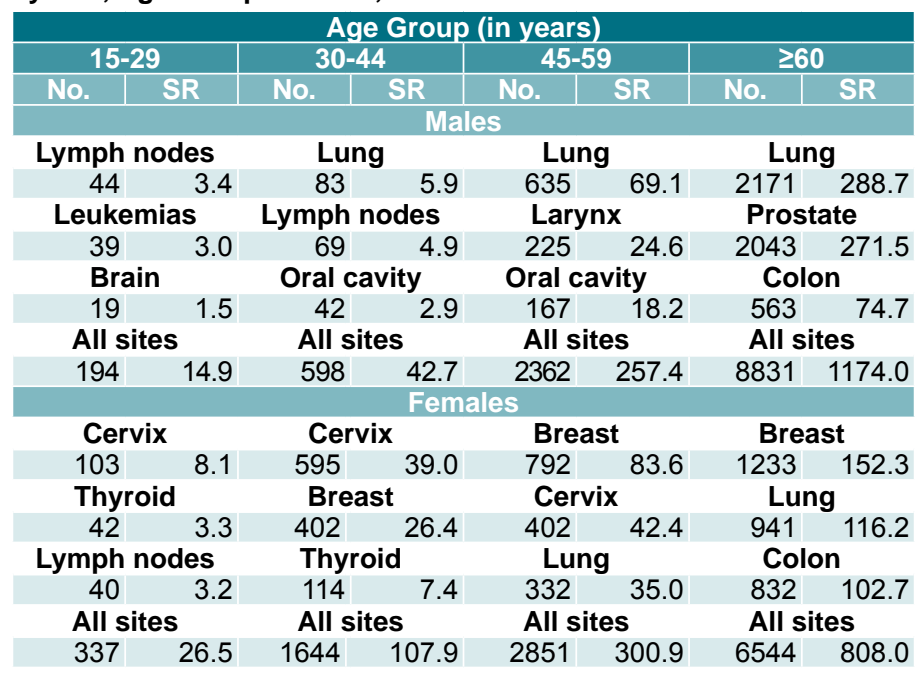

No.: Average annual number of cases

SR: Specific rate per 100,000 population

Source: National Cancer Registry
Lung cancer was the leading cause of cancer death in the Cuban population as a whole (Table 6), with a higher mortality in men than in women. Prostate cancer was the second leading cause of cancer death among men, and breast cancer was second among women, followed by colon cancer as the third leading cause of cancer death in both sexes.

Cancer mortality in the group aged $<15$ years was very low, representing $0.4 \%$ of all cancer deaths. An average of 95 children died each year. Mortality was also low in the group aged 15-29 years for both sexes; the sites showing the highest risks of dying were the hematopoietic system, lymph nodes and brain. In the group aged $\geq 30$ years, lung cancer was the most common cause of death in men, as it was among women aged $\geq 45$ years (Table 7).

\section{DISCUSSION}

The shift in cancer incidence trends between 1990-1995 and 1996-2003 may be the result of improved NCR data quality in the latter period, stemming from better organization and control of the number of cases reported by hospitals, the increase in histologically-verified cases, and the reduction in cases reported only by death certificate (from $27 \%$ in 1996 to $18 \%$ in 2003 , according to regular NCR data quality control).

Nevertheless, if the annual increase observed since 1996 continues, based on population estimates for 2015, the risk of developing cancer can be expected to increase to 153.8 per 100,000 women (11,948 cases) and 169.2 per 100,000 men (12,625 cases) by 2015 . This predicted increase will create a greater demand for material, human and financial resources for cancer detection and management.

At the same time, given the gradual increase in cancer mortality, if the current risk of dying from cancer in Cuba is maintained, an additional 2,928 deaths by 2015 can be predicted, an increase of 98.0 per 100,000 women and 168.2 per 100,000 men. These figures point to the need for more effective national cancer control efforts to meet the goal of reducing cancer mortality by $15 \%$ by 2015 .

Many countries, particularly low- and middle-income nations, face a similar situation. For this reason, international organizations emphasize the need for effective prevention measures to reduce the risk of cancer, as well as early detection programs that are the key to successful patient treatment.[29]

It may be assumed that variations in incidence and mortality among provinces are due to differences in risk factor prevalence, but no scientific evidence has been published to support this assumption. Nevertheless, the elevated risk of developing and dying from cancer in Havana City province may be partially explained by population aging and density.[30-32] The Cuban capital and surrounding area is the most densely populated province in the country with 3007.2 inhabitants per $\mathrm{km}^{2}$.[33] It also has the second oldest population ( $18.9 \%$ aged $\geq 60$ years), surpassed only by Villa Clara $(20 \%$ aged $\geq 60)$.[15]

Major differences in the risk of developing cancer were observed between Havana City, Santiago de Cuba and Granma provinces and the rest of the country. Specifically, this risk was above the national average among women in Pinar del Río and 
Figure 3: Cancer Mortality in Cuba by Sex, 1990 to 2007

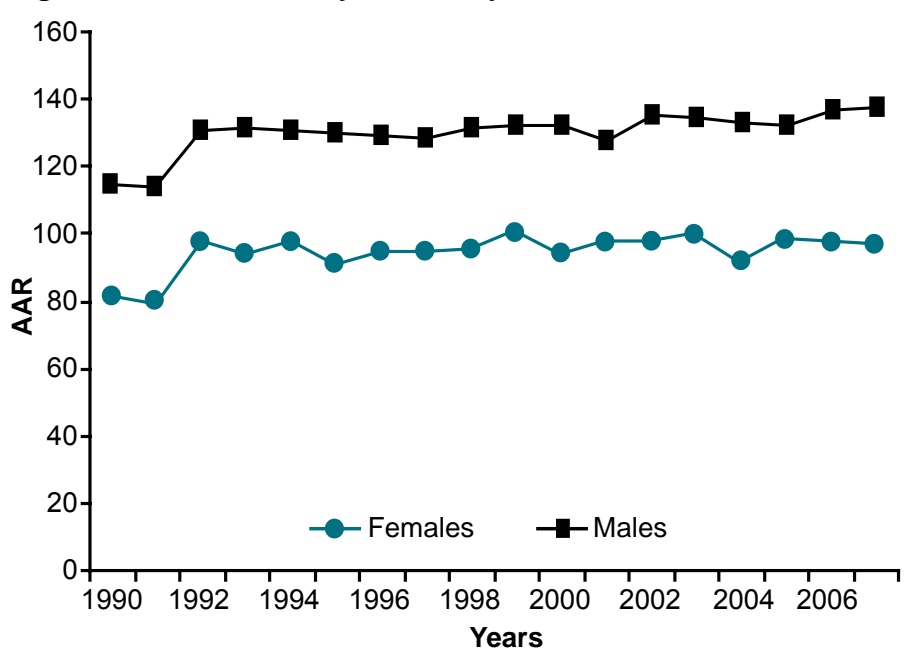

AAR: Age-adjusted rate (standard world population) per 100,000 population Source: Ministry of Public Health, National Statistics Division

Villa Clara, who exhibited high risk of developing breast and lung cancer. Risk of developing cervical and colon cancer was also high among women in Pinar del Río, as was risk of developing colon cancer among women in Villa Clara. Determining the causes contributing to these patterns is complex, since they vary by site, sex, age group and risk factor prevalence.

The cancer incidence pattern by sex in Cuba is similar to that observed in developed countries, although the proportion of new lung cancer cases among both Cuban men (27.2\%) and women $(18.26 \%)$ is substantially higher than global rates $(16.6 \%$ and $7.6 \%$, respectively).[2]

Lung cancer is the most common malignancy and the leading cause of cancer death in Cuba. The incidence rate for men is the highest in Latin America, and the rate for women is second only to Uruguay's.[2,34] Incidence of lung cancer among Cuban women is even higher than in the most developed regions.[2]

Table 5: Cancer Mortality in Cuba by Sex and Province, 2005-2007

\begin{tabular}{|c|c|c|c|c|c|c|c|c|}
\hline \multirow{3}{*}{ Province } & \multirow{2}{*}{\multicolumn{2}{|c|}{ Total }} & \multicolumn{3}{|c|}{ Males } & \multicolumn{3}{|c|}{ Females } \\
\hline & & & \multirow[b]{2}{*}{ No. } & \multicolumn{2}{|c|}{ Rate $^{*}$} & \multirow[b]{2}{*}{ No. } & \multicolumn{2}{|c|}{ Rate $^{*}$} \\
\hline & No. & $\%$ & & Crude & Adjusted & & Crude & Adjusted \\
\hline Dinar del Río & 1114 & 5.67 & 630 & 167.8 & 115.8 & 484 & 134.3 & 96.2 \\
\hline Javana & 1269 & 6.45 & 736 & 199.3 & 133.8 & 533 & 147.2 & 96.3 \\
\hline Havana City & 4597 & 23.37 & 2476 & 235.9 & 160.0 & 2121 & 186.7 & 100.5 \\
\hline Matanzas & 1236 & 6.28 & 747 & 217.6 & 144.8 & 489 & 144.4 & 93.2 \\
\hline Villa Clara & 1493 & 7.59 & 892 & 217.1 & 121.7 & 601 & 148.4 & 81.2 \\
\hline Cienfuegos & 692 & 3.52 & 402 & 197.2 & 130.4 & 290 & 147.0 & 95.8 \\
\hline Sanct & 875 & 4.45 & 509 & 215.4 & 125.1 & 366 & 160.1 & 95.3 \\
\hline de Ávila & 706 & 3.59 & 420 & 195.6 & 130.0 & 286 & 138.4 & 92.9 \\
\hline Camagüey & 1421 & 7.22 & 815 & 204.6 & 136.4 & 606 & 155.2 & 104.2 \\
\hline Las Tunas & 868 & 4.41 & 513 & 188.7 & 138.7 & 355 & 135.7 & 97.3 \\
\hline Holguín & 1644 & 8.36 & 949 & 181.0 & 128.8 & 695 & 136.4 & 94.5 \\
\hline Granma & 1299 & 6.60 & 765 & 180.6 & 133.9 & 534 & 130.2 & 98.1 \\
\hline Santiago de Cuba & 1599 & 8.13 & 916 & 174.9 & 134.3 & 683 & 130.3 & 95.0 \\
\hline Guantánamo & 736 & 3.74 & 417 & 161.3 & 130.5 & 319 & 124.7 & 100.1 \\
\hline Isle of Youth & 122 & 0.62 & 73 & 165.5 & 156.6 & 49 & 113.9 & 106.4 \\
\hline Total & 19,671 & 100.00 & 11,260 & & & 8411 & & \\
\hline Average & & & & 199.4 & 136.6 & & 149.4 & 96.4 \\
\hline
\end{tabular}

No.: Number of deaths

*per 100,000 population

Source: Ministry of Public Health, National Statistics Division
Figure 4: Risk of Dying from Cancer in Cuba by Sex and Province, 2005 to 2007

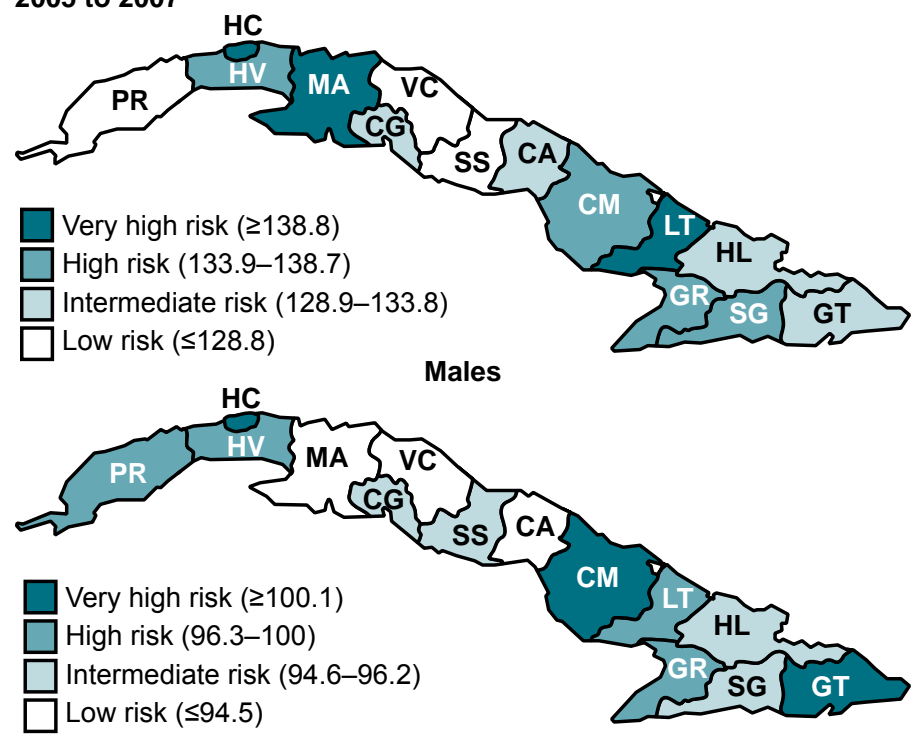

Females

PR: Pinar del Río, HV: Havana, HC: Havana City, MA: Matanzas,

VC: Villa Clara, CG: Cienfuegos, SS: Sancti Spíritus, CA: Ciego de

Ávila, CM: Camagüey, LT: Las Tunas, HL: Holguín, GR: Granma, SG:

Santiago de Cuba, GT: Guantánamo

Average annual rates per 100,000 population

Source: Ministry of Public Health, National Statistics Division

As smoking is the primary risk factor involved, educational campaigns and no-smoking measures in other countries have led to a steady decline in the disease and, consequently, mortality.[35,36] In Cuba, however, actions to discourage or eliminate tobacco use have been insufficient so far, and smoking-attributable mortality is very high.[37] Cuba has been a major tobacco consumer for many years, $[37,38]$ and smoking prevalence has not declined as in other countries.[39,40] According to the 2001 National Survey on Risk Factors and Chronic Diseases,[41] smoking prevalence in Cuba was about $32 \%$, and the rate for women was 23\%,[42] which is very high compared to rates reported elsewhere in the Americas.

Breast cancer is the most common malignancy affecting Cuban women with incidence comparable to the global rate and rising. $[2,43,44]$ This increase may be due to changes in exposure to reproductive determinants and changes in nutrition in the last 50 years.[45] Breast cancer rates are highest in developed countries, except Japan. In the United States, breast cancer accounts for $15 \%$ of all new cancer cases among women, with a rate of 125.3 per 100,000 population.

High incidence has also been reported in some South American countries, particularly Uruguay and Argentina. [2] Although the rate in Cuba is higher than in less developed countries, it is comparable to the Caribbean and Central America region as a whole.[33]

This study found that cervical cancer was the most common malignancy affecting Cuban women aged $15-44$ years. This may be associated with greater exposure at younger ages to risk factors related to 
Table 6: Cancer Mortality in Cuba by Site and Sex, 2005 to 2007

\begin{tabular}{|c|c|c|c|c|}
\hline Site & No. & $\%$ & CR & AAR \\
\hline \multicolumn{5}{|c|}{ Males } \\
\hline Lung & 3065 & 27.2 & 54.3 & 38.6 \\
\hline Prostate & 2274 & 20.2 & 40.3 & 23.3 \\
\hline Colon & 705 & 6.3 & 12.5 & 8.2 \\
\hline Larynx & 608 & 5.4 & 10.8 & 8.0 \\
\hline Stomach & 500 & 4.4 & 8.9 & 6.2 \\
\hline Hematopoietic system & 461 & 4.1 & 8.2 & 6.2 \\
\hline Esophagus & 420 & 3.7 & 7.4 & 5.6 \\
\hline Pancreas & 376 & 3.3 & 6.7 & 4.7 \\
\hline Bladder & 343 & 3.1 & 6.1 & 3.9 \\
\hline Liver & 334 & 3.0 & 5.9 & 4.2 \\
\hline All sites & 11,260 & - & 199.4 & 136.6 \\
\hline \multicolumn{5}{|c|}{ Females } \\
\hline Lung & 1536 & 18.3 & 27.3 & 18.3 \\
\hline Breast & 1247 & 14.8 & 22.2 & 14.7 \\
\hline Colon & 974 & 11.6 & 17.3 & 9.7 \\
\hline Cervix & 450 & 5.4 & 8.0 & 5.7 \\
\hline Pancreas & 363 & 4.3 & 6.4 & 4.0 \\
\hline Hematopoietic system & 362 & 4.3 & 6.4 & 4.6 \\
\hline Liver & 351 & 4.2 & 6.2 & 3.8 \\
\hline Uterus unspecified & 347 & 4.1 & 6.2 & 4.2 \\
\hline Uterus & 294 & 3.5 & 5.2 & 3.5 \\
\hline Stomach & 284 & 3.4 & 5.0 & 3.1 \\
\hline All sites & 8411 & - & 149.4 & 96.4 \\
\hline
\end{tabular}

No.: Average annual number of deaths

CR: Average crude rate per 100,000 population

AAR: Age-adjusted rate (standard world population) per 100,000 population

Source: Ministry of Public Health, National Statistics Division

sexual behavior, such as sexually transmitted diseases (STIs), specifically Human Papillomavirus (HPV), the primary factor associated with the etiology of this disease.[45] Additionally, many women do not go to their family doctor for regular Pap screening. $[44,46]$ The high risk of death from cervical cancer among women aged 30-44 years is undoubtedly related to late detection of the disease and is a matter of concern. This study confirms that incidence and mortality remain high, even though a screening program has been in place since 1968,[44] reaching $70 \%$ of women aged $20-39$ years in the period 1993-1994.[47] Coverage has since increased for that age group, but remains at $70 \%$ for all age groups included in the program.[5]

According to the literature, an effective screening program should cover $>80 \%$ of the target population.[48] Introduction of the HPV vaccine may boost prevention efforts by reducing highrisk varieties of the virus (HPV types 16 and 18). Unfortunately, the vaccine is too expensive for many developing countries, and thus the need remains to continue broadening coverage of and access to screening programs.[49]

Prostate cancer is a priority of the national cancer control strategy due to rising incidence and mortality. The reasons for increased incidence have not been fully explained,[50] although detection at advanced stages of the disease may be a factor, since Cuba has not organized an early detection program through either PSA (prostate-specific antigen) or digital rectal exam screening.[51] Etiological factors are also unclear. Results from a Cuban study on prostate cancer risk factors substantiate the hypothesis that STIs may play a role but did not rule out hormonal factors associated with sexual activity or as cofactors with STIs.[52,53] High mortality may be due not only to late detection but also to low risk perception and non-compliance with diagnostic and treatment protocols.[51]

With regard to childhood cancer, no differences were found in the principal diagnostic groups, compared to previous studies showing leukemias, lymphomas and central nervous system tumors to be the most common cancer types in this age group.[54,55] As in the rest of the world, leukemias predominate,[56,57] accounting for $30-40 \%$ of all malignancies observed in children aged $<15$ years; of these, acute lymphoblastic leukemia-the most common site in countries with high socioeconomic development and in all industrialized countries-has the highest incidence $(75 \%$ of all leukemia cases).[58]

It should be noted that Cuba has over 40 years experience maintaining a national, population-based cancer registry. Maintenance and upgrading of this system is a priority of the Ministry of Public Health, resulting in continuously improved data. Information gathered is being used ever more frequently in decision-making, not only for the design and evaluation of cancer control measures but also for planning, purchase and allocation of resources for cancer treatment and care.

\section{CONCLUSIONS}

Cancer incidence and mortality are increasing in Cuba. The sites posing greatest risk of developing and dying from cancer are the lung, female breast, prostate, colon and uterine cervix. These
Table 7: Cancer Mortality in Cuba by Age Group, Site, and Sex, 2005 to 2007

\begin{tabular}{|c|c|c|c|c|c|c|c|c|c|}
\hline \multicolumn{10}{|c|}{ Age Group (in years) } \\
\hline \multicolumn{2}{|c|}{$<15$} & \multicolumn{2}{|c|}{$15-29$} & \multicolumn{2}{|c|}{$30-44$} & \multicolumn{2}{|c|}{$45-59$} & \multicolumn{2}{|c|}{$\geq 60$} \\
\hline No. & SR & No. & SR & No. & SR & No. & SR & No. & SR \\
\hline \multicolumn{10}{|c|}{ Males } \\
\hline \multicolumn{2}{|c|}{$\begin{array}{l}\text { Hematopoietic } \\
\text { system }\end{array}$} & \multicolumn{2}{|c|}{$\begin{array}{l}\text { Hematopoietic } \\
\text { system }\end{array}$} & \multicolumn{2}{|c|}{ Lung } & \multicolumn{2}{|c|}{ Lung } & \multicolumn{2}{|c|}{ Lung } \\
\hline 20 & 1.8 & 25 & 2.1 & 64 & 4.1 & 604 & 64.9 & 2396 & 288.6 \\
\hline \multicolumn{2}{|c|}{ Brain } & \multicolumn{2}{|c|}{ Lymph nodes } & \multicolumn{2}{|c|}{$\begin{array}{l}\text { Hematopoietic } \\
\text { system }\end{array}$} & \multicolumn{2}{|c|}{ Larynx } & \multicolumn{2}{|c|}{ Prostate } \\
\hline 11 & 1.0 & 21 & 1.8 & 39 & 2.5 & 153 & 16.5 & 2187 & 263.4 \\
\hline \multicolumn{2}{|c|}{ Lymph nodes } & \multicolumn{2}{|c|}{ Brain } & \multicolumn{2}{|c|}{ Lymph nodes } & \multicolumn{2}{|c|}{ Esophagus } & \multicolumn{2}{|c|}{ Colon } \\
\hline 6 & 0.6 & 10 & 0.8 & 35 & 2.2 & 125 & 13.4 & 593 & 71.4 \\
\hline \multicolumn{2}{|c|}{ All sites } & \multicolumn{2}{|c|}{ All sites } & \multicolumn{2}{|c|}{ All sites } & \multicolumn{2}{|c|}{ All sites } & \multicolumn{2}{|c|}{ All sites } \\
\hline 55 & 4.8 & 87 & 7.3 & 378 & 24.2 & 1879 & 202.1 & 8862 & 1067.3 \\
\hline \multicolumn{10}{|c|}{ Females } \\
\hline \multicolumn{2}{|c|}{$\begin{array}{l}\text { Hematopoietic } \\
\text { system }\end{array}$} & \multicolumn{2}{|c|}{$\begin{array}{l}\text { Hematopoietic } \\
\text { system }\end{array}$} & \multicolumn{2}{|c|}{ Breast } & \multicolumn{2}{|c|}{ Lung } & \multicolumn{2}{|c|}{ Lung } \\
\hline 13 & 1.2 & 15 & 1.4 & 129 & 8.3 & 362 & 37.2 & 1122 & 123.6 \\
\hline \multicolumn{2}{|c|}{ Brain } & Lymph & des & Cer & & Bre & & Col & \\
\hline 8 & 0.7 & 14 & 1.2 & 113 & 7.3 & 319 & 32.7 & 843 & 92.9 \\
\hline Lympl & des & $\mathrm{Br}$ & & Lur & & Cer & & Bre & \\
\hline 5 & 0.5 & 8 & 0.7 & 50 & 3.2 & 149 & 15.4 & 798 & 87.9 \\
\hline All & & All s & & All $s$ & & All s & & All si & es \\
\hline 40 & 3.7 & 74 & 6.6 & 613 & 39.4 & 1719 & 176.8 & 5965 & 657.2 \\
\hline
\end{tabular}

No.: Average annual number of deaths

SR: Average specific rate per 100,000 population

Source: Ministry of Public Health, National Statistics Division 
risks vary by age group and by geographic location. Analyses of these trends and variations are currently being used by the Ministry of Public Health's National Comprehensive Cancer Control Program to design more effective prevention and mortality reduction strategies. The data presented in this study also point to the need for expanded research in key areas, particularly to explain the high risk of cancer incidence and mortality in Havana City province, unsatisfactory results thus far of no-smoking efforts, and factors associated with breast cancer incidence and cervical cancer screening coverage. $M$ -

\section{REFERENCES}

1. Sener SF, Grey N. The global burden of cancer. J Surg Oncol. 2005 Oct 1;92(1):1-3.

2. Parkin DM, Bray F, Ferlay J, Pisani P. Global Cancer Statistics, 2002. CA Cancer J Clin. 2005 Mar-Apr;55(2):74-108.

3. World Health Organization. Plan de Acción propuesto por la OPS para la Prevención y el Control del Cáncer 2008-2015 [monograph on the Internet]. Washington: WHO; 2008 [cited 2008 Dec 22]. Available from: http://www.paho.org/ Spanish/AD/DPC/NC/pcc-proposed-plan.pdf

4. Kanavos P. The rising burden of cancer in the developing world. Ann Oncol. 2006 Jun;17 Suppl 8:viii15-viii23. Review.

5. Anuario Estadístico de Salud 2007. [Internet]. Havana: Ministry of Public Health, National Statistics Division; 2008 [cited 2008 Nov 17]. Available from: http://bvs.sld.cu/cgi-bin/wxis/ anuario/? IsisScript=anuario/iah.xis\&tag5003=an uario\&tag5021=e\&tag6000=B\&tag5013=GUEST \&tag5022=2007

6. Seuc A, Domínguez E, Galán Y. Esperanza de vida ajustada por cáncer. Rev Cubana Hig Epidemiol [serial on the Internet]. $2003 \mathrm{Apr}$ [cited 2009 Mar 17];41(1). Available from: http://scielo. sld.cu/scielo.php?script=sci_arttext\&pid=S1561$30032003000100004 \&$ Ing=es\&nrm=iso.

7. Seuc A, Domínguez E, Galán Y. La carga por morbilidad del cáncer. Cuba, año 2000. Rev Cubana Hig Epidemiol [serial on the Internet]. 2006 Aug [cited 2009 Mar 17]; 44(2). Available from: http://scielo.sld.cu/scielo.php?script=sci arttext\&pid $=$ S1561-30032006000200003\&lng $=\bar{e}$ s\&nrm=iso.

8. Huerta E, Grey N. Cancer Control Opportunities in Low- and Middle-income Countries. CA Cancer J Clin. 2007 Mar-Apr;57(2):72-4.

9. Pisani P. The Cancer problem in developing countries. In: Tanneberger S, Cavalli F, Pannuti $F$, editors. Cancer in developing countries. The great challenge for oncology in the 21st Century. Munich: Zuckschwerdt; 2004. p. 21-5.

10. Ngoma T. World Health Organization cancer priorities in developing countries. Ann Oncology. 2006 Jun;17 Suppl 8:viii9-viii14.

11. Rodríguez A, Álvarez L. Repercusiones del envejecimiento de la población cubana en el sector salud. Rev Cubana Salud Pública. 2006;32(2):178-82.

12. Cuba. Oficina Nacional de Estadísticas. Sistema de Información Estadística Nacional de Demografía. Havana: National Statistics Bureau; 2004

13. Rojas F. Situación, sistema y recursos humanos en salud para el desarrollo en Cuba. Rev Cubana Salud Pública. 2003;29(2):157-69.

14. Anuario Estadístico de Salud 2000-2007. Havana: Ministry of Public Health, National Statistics Division; 2000-2007. [cited 2008 Nov]. Available from: Available from: http://bvs.sld. cu/cgi-bin/wxis/anuario/?IsisScript=anuario/iah. $x i s \&$ base $=$ anuario \&lang $=e$

15. El Envejecimiento de la Población Cubana 2007. Cuba y sus territorios [monograph on the Internet]. Havana: National Statistics Bureau; 2008 [cited 2008 Nov]. Available from: http://www.one. cu/envejecimiento2008.htm.

16. Cuba: Proyección de la Población. Nivel Nacional y Provincial, Período 2010 - 2030 [mono- graph on the Internet]. Havana: National Statistics Bureau; [cited 2008 Nov]. Available from: http://www.one.cu/proyecciones $\% 20 \mathrm{de} \% 20$ la\%20poblacion\%202010\%202030.htm.

17. Barros O. Escenarios demográficos de la población de Cuba para el próximo milenio [thesis]. Havana: University of Havana; 2000.

18. Center for Population and Development Studies. El estado actual y perspectivo de la población cubana: Un reto para el desarrollo territorial sostenible [monograph on the Internet]. Havana: National Statistics Bureau. [cited 2008 Dec]. Available from: http://www.one.cu/estadoactual.htm.

19. Fernández L. Sistema de Información para el Registro Nacional del Cáncer [thesis]. Havana: National Oncoloy and Radiobiology Institute; 1985.

20. Rodríguez A, Martín AA. El Registro Nacional de Cáncer de Cuba. Procedimientos y resultados. Rev Brasileira de Cancerologia. 2001;47(2):171-7.

21. Fernández $L$, Caraballoso $M$, Rodríguez $L$. Proposición de un Sistema Automatizado para Procesar la Información del Registro Nacional del Cáncer. Rev Cubana Adm Salud. 1984;10(4):341-6.

22. Galán $Y$, Martín A, Rodríguez A, Graupera M, Luaces $P$, Fernández L. Estimación de la integridad de casos del Registro Nacional de Cáncer de Cuba. Rev Cubana Oncol. 1996;12(1):37-42.

23. Lage $M$, Carballoso $M$, Azcué $M$. Las posibilidades de reducción de la mortalidad por cáncer en Cuba. Análisis para un Programa Nacional. Rev Cubana Oncol. 1987;3(2):101-30.

24. Rodríguez A, Martín A, Camacho R. El programa nacional de control de cáncer en Cuba. Rev Brasileira de Cancerologia. 1998:44(2):119-29.

25. Proyecciones de la salud pública de Cuba para el año 2015 [homepage on the Internet]. Havana: Ministry of Public Health; 2006 [cited 2008 Nov]. Enfermedades no transmisibles y otros daños para la salud. Tumores malignos; [1 screen]. Available from: http://salud2015.sld.cu/factoresrelacionados-con-el-ambiente/plonearticlemultipage.2006-03-24.5255686058/tumores-malignos.

26. Martín AA, Galán YH, Rodríguez AJ, Graupera $M$, Lorenzo Luaces $P$, Fernández LM, et al. The Cuban National Cancer Registry: 1986-1990. Eur J Epid. 1998 Apr;14(3):287-97.

27. Doll $R$, Smith $P$. Comparison between registries: Age-standardized rates. In: Waterhouse J, Muir CS, Shanmugaratnam S, Powell J, editors. Cancer incidence in five continents. Lyon: IARC; 1982. p. $671-75$

28. Pan American Health Organization. Clasificación Internacional de Enfermedades para Oncología (CIE-O). 1st ed. Washington: Publicación Científica No. 345;1977.

29. Boyle $P$, Anderson B, Andersson L, Ariyaratne Y, Auleley G, Barbacid M, et al. Need for global action for cancer control. Ann Oncol. 2008 Sep;19(9):1519-21.

30. Ahmad S, O'Mahony MS. Shift in the burden of cancer towards older people-a retrospective population-based study. Int J Clin Pract. 2007 Jun;61(6):931-6.

31. Allender S, Foster C, Hutchinson L, Arambepola C. Quantification of urbanization in rela- tion to chronic diseases in developing countries: a systematic review. J Urban Health. 2008 Nov;85(6):938-51. Epub 2008 Oct 18.

32. Lence JJ, Camacho R. Cáncer y transición demográfica en América Latina y el Caribe. Rev Cubana Salud Pública [serial on the Internet]. 2006 Sep [cited 2009 Mar 17];32(3). Available from: http://scielo.sld.cu/scielo.php?script=sci_ arttext\&pid=S0864-34662006000300010\&lng $=\bar{e}$ s\&nrm=iso.

33. Center for Population and Development Studies. Panorama Económico y Social. Cuba 2008 [monograph on the Internet]. Havana: National Statistics Bureau; [cited 2008 Nov]. Available from: http://www.one.cu/panoramaeconomico2008.htm.

34. Barrios E, Galán Y, Sancho-Garnier H, Sabini G, Musé IM. Epidemiología. In: Unión Internacional contra el Cáncer, editor. Prevención del Cáncer. Estrategias basadas en la Evidencia. Una Guía de la UICC para América Latina. UICC; 2006. p. 13-26.

35. Corrao MA, Guindon GE, Sharma N, Shokoohi DF, editors. Tobacco Control Country Profiles. 1st ed. Atlanta (GA): American Cancer Society; 2000.

36. Peto R, Darby S, Deo H, Silcocks P, Whitley E, Doll R. Smoking, smoking cessation, and lung cancer in the UK since 1950: combination of national statistics with two casecontrol studies. BMJ. 2000 Aug 5;321(7257):323-9.

37. Varona P, Herrera D, García R, Romero T, Venero S. Mortalidad atribuible al tabaquismo. Rev Cubana Salud Pública. 2009;35(2):1-13.

38. González S, Suárez N, Cáceres C, Conde C, Camacho R. Características del hábito de fumar en Cuba. Rev Venezolana de Oncología. 1993;5:93-5.

39. Bray F, Tyczynski JE, Parkin DM. Going up or coming down? The changing phases of the lung cancer epidemic from 1967 to 1999 in the 15 European Union countries. Eur J Cancer. 2004 Jan;40(1):96-125.

40. Jha P, Chaloupka FJ, Corrao M, Jacob B. Reducing the burden of smoking world-wide: effectiveness of interventions and their coverage. Drug Alcohol Rev. 2006 Nov;25(6):597-609.

41. Segunda Encuesta Nacional de Factores de Riesgo de Enfermedades Crónicas no Transmisibles en Cuba. Informe de Trabajo. Havana: National Institute of Hygiene, Epidemiology and Microbiology; 2002.

42. Shafey O, Dolwick S, Guindon GE, editors. Tobacco Control Country Profiles 2003. 2nd ed. Atlanta: American Cancer Society; 2003.

43. Bray F, McCarron P, Parkin DM. The changing global patterns of female breast cancer incidence and mortality. Breast Cancer Res. 2004;6(6):229-239. Epub 2004 Aug 26.

44. Torres P, Guerra M, Galán Y, García M, Lezcano $M$, Fernández L. Incidencia y mortalidad por cáncer en la mujer cubana. Trienio 20002002. Rev Cubana Med [serial on the Internet]. 2007 Sep [cited 2009 Mar 17];46(2). Available from: http://scielo.sld.cu/scielo.php?script=sci arttext\&pid=S0034-75232007000200007\&Ing $=\bar{e}$ s\&nrm=iso. 
45. Torres R, Gran M. Panorama de salud de la mujer cubana. Rev Cubana Salud Pública. 2003;29(3):198-208.

46. Pan American Health Organization. Evaluación del programa de control del cáncer de cuello de útero en Cuba. Informes Breves. Boletín de la Oficina Panamericana de la Salud. 1996;121(6):577-81.

47. Rodríguez A, Lence J, Cabezas E, Camacho R. Programa Nacional de Diagnóstico Precoz del Cáncer Cérvicouterino ¿Qué hacer y por qué? Rev Cubana Med General Integral. 1994;10(3):220-4.

48. Sankaranarayanan R, Budukh A, Rajkumar A. Effective screening programmes for cervical cancer in low- and middle-income developing countries. Bull World Health Organization. 2001;79(10):954-62. Epub 2001 Nov 1.

49. Clifford GM, Gallus S, Herrero R, Muñoz N Snijders PJ, Vaccarella S, et al. Worldwide distribution of human papillomavirus types in cytologically normal women in the International Agency for Research on Cancer HPV prevalence surveys: a pooled analysis. Lancet. 2005 Sep 17-23;366(9490):991-8.

50. Galán $Y$, Guerra M, Fernández L, Camacho R Incidence, mortality and survival from prostate cancer in Cuba, 1977-1999. Eur J Cancer Prevention. 2004 Oct;13(5):377-81.

51. National Oncology Group. Propuesta para abordar el problema Cáncer de Próstata. Unpublished working paper. 2006.
52. Fernández L, Galán $Y$, Jiménez $R$, Gutiérrez $A$, Guerra M, Pereda C, et al. Estudio de casos y controles sobre factores de riesgo de cáncer de próstata. Rev Cubana Salud Pública. 2005 JulSep;31(3):174-81.

53. Fernández L, Galán $\mathrm{Y}$, Jiménez R, Gutiérrez A, Guerra M, Pereda C, et al. Sexual behaviour, history of sexually transmitted diseases and the risk of prostate cancer: a case-control study in Cuba. Int J Epidemiol. 2005 Feb;34(1):193-7. Epub 2004 Sep 16.

54. Caraballoso M. Cuba: National Cancer Registry 1970-1981. In: Parkin DM, Stiller CA, Draper GJ, Bieber CA, editors. International Incidence of Childhood Cancer. Lyon: IARC; 1988. p. 127-30.

55. Martín A, Valdés A, Longchong $M$, Grueiro $S$. Incidencia del cáncer infantil en Cuba (19831987). Rev Cubana Oncol. 1994;10(1-2):50-8.

56. Parkin DM, Kramárová E, Draper GJ, Masuyer E, Michaelis J, Neglia J, et al, eds. International Incidence of Childhood Cancer, Vol. II. IARC Scientific Publication No. 144. Lyon: IARC; 1998.

57. Steliarova-Foucher E, Stiller C, Kaatsch Berrino F, Coebergh J, Lacour B, et al. Geographical patterns and time trends of cancer incidence and survival among children and adolescents in Europe since the 1970s (the ACCIS project): an epidemiological study. Lancet. 2004;364(9451):2097-105.

58. Fajardo A, Mejía JM, Hernández L, Mendoza $H$, Garduño J, Martínez MC. Epidemiología descriptiva de las neoplasias malignas en niños. Rev Panamericana Salud. 1999;6(2):75-88.

\section{THE AUTHORS}

Yaima Galán Alvarez (Corresponding Author: yaima@infomed.sld.cu), mathematician and master of public health. Associate researcher, professor and head of the National Cancer Registry Department, National Cancer Control Unit, Ministry of Public Health, Havana, Cuba.

Leticia Fernández Garrote, biostatistician. Senior researcher, National Oncology and Radiobiology Institute (INOR) and consulting professor, National School of Public Health, Havana Cuba.

Priscila Torres Babié, oncologist, National Cancer Registry, National Cancer Control Unit, Ministry of Public Health, Havana, Cuba.

Mariela García Jordán, odontologist and master of public health, National Cancer Registry, National Cancer Control Unit, Ministry of Public Health, Havana, Cuba.

Submitted: June 20, 2008

Approved for publication: June 8, 2009

\section{Forum 2009: GlobalForum FOR HEALTH RESEAACH} ron Hetry

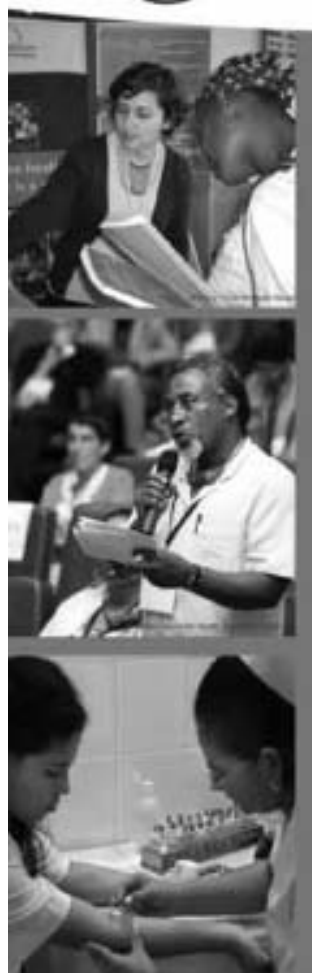

The Global Forum for Health Research is pleased to announce that its 2009 annual Forum will take place in Havana, Cuba from 16-20 November 2009 at the invitation of the Ministry of Public Health. It will focus on incentives and new approaches to strengthen both social and technological innovation for health and health equity.

Who should attend?

Forum 2009 will bring together some 800 decision-makers in funding, research and policy to engage in dialogue, identify lessons leamed from experience and identify pathways to solutions. You will have the opportunity to network with participants from health-and science-related ministries, R\&D institutions and academia, development agencies and foundations, nongovernmental organizations, civil society, the private sector and the media from around the world.

\section{What is the theme?}

"Innovation for health" encompasses the entire process from the generation of new ideas; to their transformation into useful services, products, methods, management practices and policies; and their implementation. You will be able to learn about and discuss topics such as building effective national health innovation systems, social entrepreneurship for health, knowledge translation platforms, "innovation indicators* for emerging countries and global innovation policy research networks.

\section{For more information about the Global Forum for Health Research and Forum 2009, and to sign up} for the Forum 2009 news list, visit our web site www.globalforumhealth.org.

$$
\text { Registration opens } 1 \text { March. }
$$

The Global Forum for Health Research is an independent international organization committed to demonstrating the essential role of research and innovation for health and health equity, benefiting poor and marginalized populations. 